\title{
Renata Suchocka
}

Uniwersytet im. Adama Mickiewicza w Poznaniu

\section{Meandry etnicznych i narodowych identyfikacji}

STRESZCZENIE Celem opracowania jest zwrócenie uwagi na meandry identyfikacji w tych społeczeństwach, w których identyfikacja jest coraz czéściej przedmiotem wyboru, a nie „dziedziczności”. Przedmiot rozważań obejmuje złożone identyfikacje występujące w państwach wielonarodowych i wieloetnicznych, różne identyfikacje zamieszkujących je mieszkańców i obywateli, imigrantów, a zwłaszcza ich potomków, w tym identyfikacje podwójne lub kosmopolityczne, konstruowane, a nie „przekazane” przez przodków. Co rzeczywiście oznaczają deklaracje traktowane jako dotyczące identyfikacji narodowych (etnicznych)? Czy informują o identyfikacji z narodem, ojczyzną, państwem? Relacje pomiędzy różnymi rodzajami identyfikacji narodowych i (lub) etnicznych mogą określać postawy ludzi wobec państwa zamieszkania, narodu i ojczyzny osiedlenia oraz pochodzenia (kraju przodków). Znajomość tych relacji jest szczególnie ważna dla interpretowania deklarowanych złożonych identyfikacji, a także zrozumienia konwersji narodowej.

\section{SŁOWA KLUCZOWE}

IDENTYFIKACJA NARODOWA, IDENTYFIKACJA ETNICZNA, TOŻSAMOŚĆ SPOŁECZNA, IDENTYFIKACJA ZŁOŻONA, IMIGRANCI 


\section{Wprowadzenie}

Identyfikacja narodowa (etniczna) w homogenicznych etnicznie lub narodowo społeczeństwach wydaje się dość oczywista, gdy przynależność do określonej grupy i kultury jest równoznaczna z obywatelstwem jednonarodowego państwa, a ojczyzna prywatna jest równocześnie ojczyzną ideologiczną. Zagadnienia dotyczące identyfikacji w takiej sytuacji zostały przekonująco przedstawione przez socjologię, bazującą na klasycznych, historycznych koncepcjach narodu, zgodnie z którymi identyfikacja ta jest „dana” jednostce, ukształtowana w procesie socjalizacji i wychowania oraz niepodlegająca wyborom.

Inaczej dzieje się w państwach wielonarodowych oraz wieloetnicznych, gdy pojawiają się różne identyfikacje zamieszkujących je mieszkańców i obywateli, imigrantów, a zwłaszcza ich potomków, w tym identyfikacje podwójne lub kosmopolityczne, konstruowane, a nie „przekazywane” przez przodków. Te kwestie podejmowane są przez zwolenników konstruktywistycznych, zwłaszcza postmodernistycznych koncepcji narodu, np. Rogersa Brubakera (1998).

Celem tego opracowania jest zwrócenie uwagi na meandry identyfikacji w tych społeczeństwach, w których identyfikacja jest coraz częściej przedmiotem wyboru, a nie „dziedziczności”. Uznaję za zasadne oddzielenie identyfikacji narodowej i etnicznej, aczkolwiek wspólnota (grupa) narodowa może być równocześnie grupą etniczną . Identyfikacja etniczna odnosi się do łączności z grupami etnicznymi, utworzonymi przez członków mniejszości osiadłych lub imigranckich, natomiast narodowa wiąże się z łącznością z grupą dominującą pod względem liczebności w państwie zamieszkania lub innym. Koncentruję się na identyfikacjach tych osób, które trwale bądź względnie trwale związane są z państwem zamieszkania. Pomijam identyfikacje pierwszego pokolenia imigrantów oraz transmigrantów, których aktywność w ponadnarodowych przestrzeniach, równoczesna przynależność do dwóch społeczeństw, a raczej dwóch społeczności lokalnych skłania do podwójnych identyfikacji i podwójnego obywatelstwa².

\section{Identyfikacje etniczno-narodowe a tożsamość jednostki i zbiorowości}

Ludzie identyfikują się z różnymi grupami, zbiorowościami i kategoriami społecznymi - zawodowymi, klasowymi, religijnymi, etnicznymi, narodowymi, rodziną, pokoleniem, osobami tej samej płci itp., tworząc hierarchiczne struktury identyfikacyjne, wyznaczające ich jednostkowe tożsamości. Traktuję identyfikacje jako elementy składowe tożsamości społecznej jednostki.

Tożsamość jednostki w rozumieniu Erika Eriksona (2000), twórcy terminu, obejmuje zintegrowane różnorodne identyfikacje, łączy poczucie, że jest się kimś szczególnym, z równoczesnym zintegrowaniem w ramach społecznego układu odniesienia, w którym jednostka pełni określone role.

Antonina Kłoskowska (1992, s. 133) twierdzi, że na tożsamość jednostki składa się potrójne samookreślenie się człowieka wyrażające jego łączność z najszerszą zbiorowością

\footnotetext{
${ }^{1}$ Grupa etniczna wyrasta z przeświadczenia, że przynajmniej większość jej członków łączy wspólne pochodzenie, że wywodzą się z jednego plemienia lub plemion bliskich sobie. „Za dwa bieguny grupy etnicznej uważa się często plemiona i narody" (Waldenberg, 2000, s. 32). Pomijam tu w artykule dyskusje dotyczące czynnika konstytuującego narody (etnos czy demos), uznania za narody wspólnot mających własne państwo, protonarodów, członków tych grup etnicznych, którzy uważają się za naród, a także wątpliwości związanych z kryterium liczebności. Zaproponowane odróżnienie pełni wyłącznie funkcję instrumentalną.

2 Jest to odrębne zagadnienie, które zostało przeze mnie szczegółowo przedstawione w innej pracy (Suchocka, 2014, s. 93-107).
} 
społeczną, z różnymi jej subkategoriami oraz wynikające z doświadczenia jego własnej niepowtarzalności. Zbiorowe identyfikacje narodowe lub etniczne, podzielane przez członków zbiorowości społecznych, odnoszące się do zbiorowości jako wspólnoty, wyznaczają narodową i odpowiednio etniczną tożsamość. Zgadzam się z poglądem, że tożsamość narodowa (etniczna) jest tożsamością zbiorową, natomiast w odniesieniu do jednostki można mówić o jej identyfikacji narodowej (etnicznej) (Kłoskowska, 1996, s. 104). Kłoskowska wskazuje na złożoność relacji zachodzących pomiędzy narodowymi identyfikacjami jednostek a walencją narodową, czyli przyswojeniem kultury uznawanej za własną, obejmującą kompetencję kulturową oraz wynikające z niej poczucie wspólnoty i bliskości (s. 110-111).

Tożsamość jednostki to konfiguracja jej identyfikacji z różnymi kategoriami społecznymi, grupami społecznymi czy zbiorowościami społecznymi, w tym z grupą etniczną, narodem czy Europą. Identyfikacje jednostek nie mają stałego charakteru, zarówno ze względu na ich siłę, jak i występujące aktualnie konfiguracje. Po pierwsze, oznacza to, że w różnych momentach biografii człowieka mogą pojawiać się i zanikać identyfikacje z pewnymi kategoriami społecznymi; po drugie, że identyfikacje te mogą być słabsze lub silniejsze, tworząc nowe kombinacje zhierarchizowanych autodefinicji.

Tożsamość jednostkowa (osobista) wyraża odrębność jednostki, to, co odróżnia ją od innych. Tożsamość społeczna wiąże się z cechami przypisywanymi jednostce przez innych ${ }^{3}$. Według Barbary Szackiej socjologa interesuje nie tyle tożsamość osobista, związana z postrzeganiem siebie jako osoby niepowtarzalnej, ile tożsamość społeczna jednostki jako rezultat przynależności człowieka do różnych grup i kategorii społecznych (Szacka, 2008: 154).

Henri Tajfel (1972, s. 31) traktuje tożsamość społeczną jako „wiedze jednostki o przynależności do różnych grup łącznie z pewnym emocjonalnym i wartościującym znaczeniem przywiązywanym do członkostwa w grupie", z kolei John C. Turner (1992, s. 84), nawiązując do koncepcji Tajfla, nazywał tożsamością społeczną zespół społecznych identyfikacji, którymi posługuje się osoba w definiowaniu siebie.

Indywidualne identyfikacje i zbiorowe tożsamości, jak np. etniczna, narodowa czy europejska, rozumiane jako esencje lub jako konstrukcje, to nie tylko efekt odmiennych ujęć teoretyczno-metodologicznych, lecz również, a może przede wszystkim, odzwierciedlenie zmian faktycznie zachodzących we współczesnych społeczeństwach, których członkowie inaczej postrzegają siebie samych w relacji z członkami grup własnych i odmiennymi w grupach innych, obcych. Jeśli przyjąć, że tożsamości jednostkowe i zbiorowe są procesami, a tożsamość esencja i tożsamość konstrukcja to dwie odmienne formy stanowiące krańce kontinuum tożsamości, wówczas (a wydaje się to uzasadnione z empirycznego punktu widzenia) - zbiorowe tożsamości w różnym stopniu mogą zawierać cechy charakterystyczne obu form.

Identyfikacje etniczne (narodowe) są współcześnie coraz częściej rezultatem świadomych wyborów jednostek, ich konfrontacji ze standardami kulturowymi i wartościami przekazywanymi przez grupy odniesienia.

Kultura, etniczność i tożsamość związane były (i tak też ujmowane były przez badaczy), z określonym miejscem, z dającym się określić terytorium. Wiele z współcześnie

\footnotetext{
${ }^{3} \mathrm{O}$ dyskusji dotyczącej uznawania istnienia bądź nie tożsamości zbiorowych, sposobów definiowania tożsamości jed nostkowych, zbiorowych i tożsamości społecznej piszę szerzej w pracy Mieszkańcy Europy, Europejczycy i ich widnokręgi społeczne (Suchocka, 2014, s. 28-35).
} 
zachodzących procesów wymyka się zamknięciu ich w okowach terytorialności. Tak też muszą być z konieczności rozpatrywane.

Jednostki pozostające pod naciskiem wielu oddziałujących centrów wraz z ich systemami wartości, komplementarnych lub konkurencyjnych w warunkach pogranicza kultur, znajdują się w sytuacji poszukiwania własnej tożsamości, zarówno w wymiarze jednostkowym, jak i grupowym, tzn. podejmują próby autodefinicji w nowych warunkach (Suchocka, 2003, s. 91-93).

\section{Złożone identyfikacje etniczno-narodowe i konwersja}

Socjologowie na ogół zgadzali się, co do tego, że w strukturze tożsamości jednostek szczególne miejsce przypada identyfikacji narodowej (lub etnicznej), która niejednokrotnie zajmuje najwyższe lub górne szczeble tożsamościowej drabiny identyfikacyjnej. Identyfikacja narodowa i etniczna rozumiana jest jako samookreślenie się jednostki, zarówno spontaniczne, jak i w odpowiedzi na pytania, zadawane także podczas badań socjologicznych.

Co rzeczywiście oznaczają deklaracje traktowane jako dotyczące identyfikacji narodowych (etnicznych)? O czym informują? O identyfikacji z narodem, ojczyzną czy z państwem? W wielu wypadkach, gdy ktoś mówi o sobie, że jest Polakiem, Francuzem czy Niemcem wyraża równocześnie swą łączność z narodem, ziemią ojczystą i państwem narodowym. Nie jest tak jednak zawsze i nie zawsze oznacza występowanie poszczególnych więzi w takim samym stopniu, np. według Jacka Raciborskiego, Polacy identyfikują się „z państwem pojmowanym jako umiejscowienie narodu, nie zaś jako wspólnota obywateli" (2011, s. 51).

Szczególnie w społeczeństwach, w których istnieją mniejszości etniczne, zarówno osiadłe, jak i imigracyjne, te trzy wyżej wymienione rodzaje identyfikacji nie muszą współwystępować, zwłaszcza gdy pojawiają się w podwójnych identyfikacjach. Potomkowie imigrantów lub członkowie osiadłych mniejszości narodowych czy etnicznych być może w jednym z członów identyfikacji wyrażają swą łączność z miejscem urodzenia, które traktują jako ojczyznę, może z państwem, którego są obywatelami, ale niekoniecznie z dominującą wspólnotą narodową. Drugi człon identyfikacji może dotyczyć z kolei grupy narodowej lub etnicznej, do której przynależeli rodzice czy dziadowie lub ich ziemi ojczystej.

Rozpoznanie, z którym rodzajem identyfikacji mamy do czynienia, jest kluczem do zrozumienia pewnych postaw i zachowań, a także ewentualnych konwersji identyfikacyjnych. Innymi słowy, nawiązuję tu do koncepcji Stanisława Ossowskiego, który nie tylko zwracał uwagę na odmienność znaczeń pojęcia „ojczyzny” jako kraju rodzinnego, narodu lub państwa, ale także - konsekwentnie - różnego rozumienia patriotyzmu. Patriotyzm wyrażać może osobisty stosunek jednostki do terytorium, do środowiska, w którym spędziła znaczną część życia czy okres dzieciństwa, tzn. stosunek do ojczyzny prywatnej (1984, s. 210). Patriotyzm może także wyrażać stosunek do ojczyzny ideologicznej, który:

nie opiera się na bezpośrednich przeżyciach jednostki względem ojczystego terytorium i na wytworzonych przez te przeżycia nawykach, ale na pewnych przekonaniach: na przekonaniu jednostki o jej uczestnictwie w pewnej zbiorowości i na przekonaniu, że jest to zbiorowość terytorialna związana z tym obszarem. Moja ojczyzna w tym ideologicznym znaczeniu - to ziemia mojego narodu (s. 210). 
Istotą tego związku jest uczestnictwo jednostki we wspólnocie narodowej. To uczestnictwo powoduje, że dzieci emigrantów, które nigdy nie widziały ziemi swoich ojców, mogą tę ziemię uważać za swoją ojczyznę (s. 210).

Różne identyfikacje etniczne i narodowe czy państwowe, a także szersze, np. europejskie, zgodnie z zasadą tworzenia tożsamości koncentrycznej (por. Machaj, 2005, s. 60), czy zgodnie z ujęciem kosmopolitycznym w rozumieniu zaproponowanym przez Ulricha Becka (2005, s. 65-67) i Edgara Grandego (2009, s. 43-45) mogą współwystępować, a nie pozostawać w relacji wzajemnego wykluczenia.

Relacje pomiędzy różnymi rodzajami identyfikacji narodowych i (lub) etnicznych, niekiedy dość złożonych, mogą określać postawy ludzi wobec państwa zamieszkania, narodu i ojczyzny osiedlenia oraz pochodzenia (kraju przodków). Dość powszechne dostrzeganie tych różnic nie zawsze jest jednak w pełni doceniane i znajduje swój wyraz w badaniach naukowych, których przedmiotem są ludzkie identyfikacje. Szczególnie jest to ważne w interpretowaniu deklarowanych złożonych identyfikacji, a także w zrozumieniu konwersji narodowej.

Badacze często koncentrują się na autodefinicjach i nie wnikają głębiej, czego te identyfikacje dotyczą, np. co oznaczają podwójne identyfikacje: polsko-niemiecka, francusko-marokańska itp. Są one niekiedy traktowane jako identyfikacje dwunarodowe, a być może jedna wyraża identyfikację z państwem osiedlenia, a druga z narodem pochodzenia. Z podobną sytuacją mamy do czynienia w sytuacji identyfikacji członków osiadłych grup etnicznych, dla których jeden człon identyfikacji wyraża łączność z grupą etniczną, a drugi z krajem, ojczyzną lub państwem osiedlenia, np. Kaszubi-Polacy lub Ślązacy-Polacy albo z narodem pochodzenia, jak Ślązacy-Niemcy.

Dzieci imigrantów i kolejne pokolenia lub członkowie mniejszości etnicznych, osoby, które urodziły się w krajach zamieszkania, stanowiących ich prywatne ojczyzny, mogą identyfikować się z obecną ojczyzną, rozumianą jako kraj urodzenia, a równocześnie zachowywać identyfikację z ojczyznami czy narodem przodków. Nie oznacza to jednak, że identyfikują się z narodem dominującym w kraju osiedlenia czy państwem.

Aktualne są pytania: z kim, z jakimi kategoriami społecznymi, zbiorowościami, grupami identyfikują się rzeczywiście osoby, pozostające zarówno przy identyfikacjach pojedynczych, jak i podwójnych, tzw. identyfikacjach „z łącznikiem” - z narodem, państwem czy ziemią ojczystą. W sytuacji, gdy nie muszą one oznaczać tego samego, odpowiedź jest szczególnie ważna. Wątpliwości budzi nawet zdefiniowanie „ziemi ojczystej”, gdy wiele osób doświadcza „uogólnionego stanu bezdomności” (Said, 1979, s. 18), gdy tożsamości odrywają się od miejsc i przestrzeni tradycyjnie im przypisanych. Dotyczy to m.in. emigrantów, imigrantów, uchodźców, ludów wysiedlonych.

W świecie diaspory, ponadnarodowych przepływów kulturowych, masowych przemieszczeń ludności, dawne próby odwzorowania świata jako zbioru regionów kulturowych czy ojczyzn zderzają się z olśniewającą mnogością postkolonialnych symulakr, podwojeń i zwielokrotnień, tak jak Indie i Pakistan najwyraźniej pojawiają się na nowo w postkolonialnej symulacji w Londynie, przedrewolucyjny Teheran odradza się z popiołów w Los Angeles, a tysiąc podobnych kulturowych marzeń odgrywa się w scenerii miejskiej i wiejskiej na całym globie. W tej kulturowej grze diaspory, znajome linie oddzielające „tu” od „tam” (...) ulegają zatarciu (Gupta, Ferguson, 2004, s. 271).

\footnotetext{
${ }^{4}$ W takiej sytuacji jednostka buduje obraz siebie, horyzontalnie otaczając się układami społecznymi, z którymi się identyfikuje. Innym sposobem budowania tożsamości jest procedura promienista, gdy jednostka identyfikuje się z kulturowo związanymi ze sobą, lecz względnie niezależnymi całościami społecznymi (Machaj, 2005, s. 60-61).
} 


\section{Identyfikacje etniczno-narodowe a układy odniesienia}

Znaczącą rolę w powstawaniu ludzkich identyfikacji odgrywają grupy odniesienia, zarówno własne, jak i inne niż własne, także obce ${ }^{5}$, zwłaszcza jeśli stają się przedmiotem aspiracji jednostek oraz skłaniają je do przynależności. Kategorie społeczne, zbiorowości społeczne i grupy społeczne stanowią społeczne układy odniesienia (Merton, 1982, s. 351-352), dostarczające jednostce wzory zachowań („normatywne”) i standardy dokonywanych porównań (,porównawcze”), formułowanych ocen i postaw (s. 290-291, 337).

Osoby należące do etnicznych osiadłych lub imigranckich mniejszości, jeśli aspirują do innej grupy, pozostają równocześnie pod presją grupy własnej, ale także tej, do której aspirują. Wydaje się, że identyfikacja etniczno-narodowa, a także konwersja są uzależnione od zaspokojenia potrzeb tych osób, w tym od ich dostępu do społecznie cenionych dóbr, przy czym zarówno cenionych w grupie własnej, jak i w grupie będącej przedmiotem aspiracji. Te dobra obejmuja zaspokojenie potrzeby akceptacji, jak również dostępu do oświaty, uzyskanie zadowalającej pracy, satysfakcjonującego poziomu dochodu, stabilnej pozycji społecznej lub zapewnienie możliwości awansu społecznego, wyższego statusu czy prestiżu.

Jeśli potrzeby jednostek nie zostają zaspokojone przez grupy odniesienia, zarówno własne, jak i będące przedmiotem aspiracji, pojawia się skłonność do konwersji identyfikacji. Chęć przynależności do grup innych (obcych) wiąże się z przyjmowaniem standardów tych grup w ocenie sytuacji własnej. Aspiracje skłaniają do porzucenia grupy własnej, która nie jest w stanie zaspokoić potrzeb wyznaczonych przez standardy wyznaczone przez grupy inne, obce. Z różnych powodów, zwłaszcza braku akceptacji przez innych, jeśli grupa stanowiąca przedmiot aspiracji nie realizuje potrzeb konwertyty, wytwarza się skłonność do zmiany identyfikacji i powrotu do dawnych „swoich”.

W zrozumieniu wyborów identyfikacji etniczno-narodowej jednostek ważna wydaje się szczególnie więź rodzinna, gdyż to ona odgrywa niebagatelną rolę w zapewnieniu łączności z grupą etniczną czy narodową. Z tego powodu, gdy trudno traktować grupy, do których należą członkowie rodziny jako negatywne grupy odniesienia, zrozumiałe staje występowanie podwójnych, łączących, niewykluczających się identyfikacji.

Można sformułować hipotezę, że aby dążenia jednostek należących do grup mniejszościowych skłaniały ku wybieraniu grup innych niż własne jako grup odniesienia i identyfikacji z nimi, socjalizacja antycypująca musi być funkcjonalna, a więc społeczeństwo powinno stwarzać możliwości awansu społecznego. Wydaje się prawdopodobne, że w takich sytuacjach częściej będą występowały identyfikacje podwójne, a nawet konwersja.

Jednostki formalnie przynależące do grupy odniesienia, np. poprzez obywatelstwo, lecz równocześnie odczuwające upośledzenie w stosunku do innych jej członków (także na skutek rzeczywistej lub odczuwanej dyskryminacji), czynią ją niejednokrotnie grupą odniesienia porównawczego, choć niekoniecznie normatywnego. Jeśli wcześniej identyfikowały się z grupą etniczną przodków, może to skłaniać do ponownej konwersji i powrotu do identyfikacji z grupą pochodzenia.

Być może poczucie upośledzenia, względne upośledzenie (Merton, 1982, s. 293), łączące się z niezaspokojeniem potrzeb jednostki, jest czynnikiem działającym także w wypadku

\footnotetext{
${ }^{5}$ Używam tutaj terminu „obce” w rozumieniu, które stosuje Merton, gdyż odwołuję się do jego koncepcji grup i układów odniesienia. Grupy uczestnictwa nie są tożsame z grupami własnymi, a grupy, do których się nie należy - z obcymi (Merton, 1982, s. 350-351). Odrębnym zagadnieniem jest relacja pomiędzy „innym” i „obcym”. Odmienność nie musi oznaczać obcości (por. Machaj, 2005, s. 56). Ulrich Beck (2005, s. 65), proponując swoje ujęcie kosmopolityzmu, podkreśla, że zgodnie z tym podejściem, inny, obcy traci swą obcość.
} 
członków większości, dominującego narodu i jest jednym z powodów skłaniających do identyfikacji z innymi, a także dotąd obcymi grupami. Nie ma przekonujących dowodów, które potwierdzałyby tę tezę i pozwalały wytłumaczyć pojawianie się identyfikacji niektórych jednostek z grupami odległymi kulturowo, np. Francuzów, Niemców czy Polaków z państwem islamskim, lecz postawienie takiej hipotezy wydaje się zasadne.

\section{Badanie identyfikacji etniczno-narodowych}

Wyniki badań dotyczące identyfikacji mogą i powinny budzić uzasadniony niepokój. Badacze wykorzystujący kafeterie gotowych odpowiedzi, określających etniczne (lub narodowe) przynależności jednostek, niejednokrotnie nie mają wystarczającej świadomości kreowania nieistniejących rzeczywistości. Respondenci dokonują wyboru spośród oferowanych możliwości, podczas gdy istota identyfikacji pozostaje poza zasięgiem poznania. Pouczające mogą być rezultaty badań przywoływane przez Tariqa Modooda - aż 90\% osób traktowanych jako przynależących do mniejszości etnicznych wybierało odpowiedź, że „na wiele sposobów myślą o sobie jako o przynależących do grupy etnicznej”. Równocześnie 2/3 badanych osób twierdziło, że myślało o sobie „na wiele sposobów” jak o Brytyjczyku, a zatem identyfikacja etniczna nie „była postrzegana jako konkurencyjna wobec bycia Brytyjczykiem” (Modood i in., 1997, s. 328-329). Do innych wniosków, zgodnie z zasadą ,jakie pytanie, taka odpowiedź”, może prowadzić „ograniczające” pytanie, a właściwie kafeteria odpowiedzi do wyboru: „jestem Brytyjczykiem”, „Brytyjczykiem-muzułmaninem”, „muzułmaninem”, „inna identyfikacja”. W sytuacji, gdy osoby badane nie muszą dokonywać wyboru między identyfikacjami, akceptacja kraju osiedlenia jest często dużo wyższa (por. Modood, 2014, s. 115).

Coraz częściej, na co wskazuje także Modood (2014, s. 113), identyfikacjom ludzi nie towarzyszą zachowania, które jednoznacznie łączą ich z określonymi grupami społecznymi, z respektowaniem norm czy uznawaniem grupowych wartości. Warstwa behawioralna odrywa się od afiliacyjnej. Możliwości jest wiele, np. osoby identyfikujące się z ojczyzną przodków nie muszą znać dobrze ich języka, mogą sporadycznie uczestniczyć w obrzędach religijnych, znać niektóre zwyczaje czy obyczaje i sporadycznie utrzymywać kontakty rodzinne. Z kolei emigranci identyfikujący się w deklaracjach z krajem osiedlenia mogą słabo znać język i kulturę kraju obecnego pobytu, posługiwać się językiem kraju pochodzenia, utrzymywać stałe kontakty z rodziną i przyjaciółmi w kraju, który opuścili.

W poniższym zestawieniu przedstawione zostały rozmaite rodzaje identyfikacji osób należących do kolejnych pokoleń imigrantów oraz wybrane możliwe przejawy zachowań wskazujących na intensywność łączności z kulturą przodków. Dopiero ustalenie wzajemnych relacji pomiędzy tymi warstwami w badaniach pozwala na rzetelniejsze poznanie rzeczywistych afiliacji ludzi. 


\section{䉳}

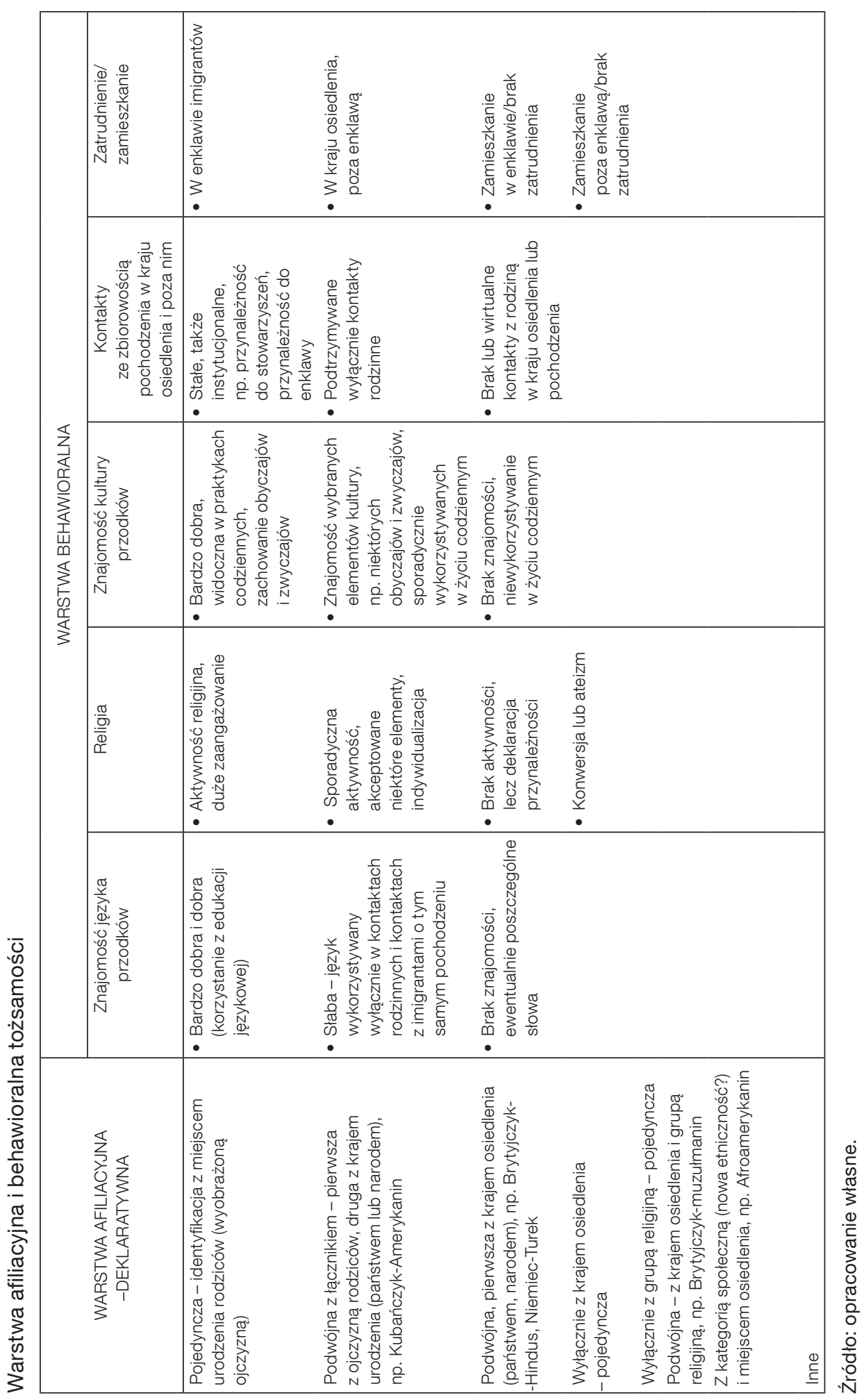


Jedną z ważnych grup odniesienia mniejszości, która sprzyja zachowaniu ciągłości identyfikacji z narodem pochodzenia, jest wspólnota religijna. Przynależność do niej wprawdzie często pozwala pogodzić się z niskim statusem i jego dyskryminującymi skutkami, ale także instytucje religijne mogą skłaniać do buntu przeciw niskiemu statusowi. Zwracał na to uwagę, przywołujący prace Talcotta Parsonsa (1972) i Donalda Younga (1937), Robert Merton (1982, s. 114-115).

Deklarowane wyznanie, identyfikacja z określoną wspólnotą religijną nie wyraża w pełni stopnia zaangażowania religijnego. Należy wziąć pod uwagę, że różne religie podlegają procesom indywidualizacji i sekularyzacjí. Potrzebę tego rozróżnienia dostrzegają sami zainteresowani, np. zajmujący się handlem Egipcjanin przedstawia się klientom (turystom) jako „Muslim, no orthodox”. Identyfikacja ze wspólnotą religijną, nawet wymieniana jako pierwsza, nie oznacza, że wymiar religijny jest dla tych osób najważniejszy. Może o niej decydować np. poczucie przynależności do rodziny czy społeczności (Modood, 2014, s. 139).

Co rzeczywiście oznacza identyfikacja Afroamerykanin? Nie jest to tzw. identyfikacja z łącznikiem, wskazuje na wspólne pochodzenie z kontynentu afrykańskiego osób, dla których miejscem urodzenia i krajem dzieciństwa jest Ameryka, wyraża łączność nie z wyobrażoną dawną ojczyzną, lecz z kategorią społeczną, która jest obecna w amerykańskim społeczeństwie. Nie daje się także ująć w kategoriach „nowych etniczności”, z uwagi na jej wewnętrzne zróżnicowanie.

Nie zawsze w parze z podawaną przynależnością etniczną idzie także znajomość języka przodków oraz posługiwanie się nim w kontaktach rodzinnych, co ilustrują między innymi niżej przytoczone wyniki badań.

Na złożony charakter ludzkich identyfikacji, a także konieczność uwzględnienia aspektu behawioralnego wskazuje m.in. analiza wyników Narodowego Spisu Powszechnego Ludności w Polsce z 2011 roku. Zawarto w nim pytania dotyczące narodowości mieszkańców Polski, w tym cudzoziemców, których pobyt na terenie Polski miał charakter stały. Po pierwsze pytano: „Jaka jest Pana(i) narodowość?”, przy czym zaznaczono, że narodowość oznacza przynależność narodową lub etniczną, której nie należy mylić z obywatelstwem. Osoby badane wybierały spośród polskiej i 13 innych narodowości wymienionych w ustawie o mniejszościach narodowych i etnicznych. Jeśli wskazywały kategorię „inna”, mogły wybrać z załączonej listy lub wpisać dowolne określenie narodowości8.

Według wyników tego spisu ludność o polskich identyfikacjach, niezależnie od tego, czy jedynych i na którym miejscu wybieranych, stanowiła 97,1\% mieszkańców Polski (37 394 tys.), natomiast 3,8\%, czyli 1468 tys. osób miało identyfikacje niepolskie (jako jedyne lub jako element podwójnych). Wśród identyfikacji, obejmujących niepolskie, 62,5\% stanowiły identyfikacje podwójne, na ogół jeden z członów obejmował polską (95,5\% deklaracji identyfikacji dualnych), najczęściej wymienianą jako pierwszą (85,9\%). Złożone identyfikacje, zawierające polską, stanowiły 59\%, a te, w których polska wymieniana była jako pierwsza

\footnotetext{
${ }^{6}$ Na przykład współczesny islam we Francji, podobnie jak katolicyzm, cechuje indywidualizacja i sekularyzacja (Roy, 2004, 2005).

${ }^{7}$ Modood stwierdza, że nie możemy zakładać, że bycie muzułmaninem oznacza dla osób tak się określających to samo. „Dla niektórych muzułmanów - podobnie jak dla wielu żydów w dzisiejszej Wielkiej Brytanii - bycie muzułmaninem jest kwestią przynależności do społeczności oraz spuścizny; dla jednych to jedynie kilka prostych nauk dotyczących współczucia, sprawiedliwości i życia po śmierci; dla drugich jest to ogólnoświatowy ruch uzbrojony w ideologię dającą odpór nowoczesności" (2014, s. 139).

${ }^{8}$ Pytanie dotyczące tej kwestii brzmiało: Czy odczuwa Pan(i) przynależność także do innego narodu lub wspólnoty etnicznej? 1. tak (proszę podać)... 2. nie, nie odczuwam.
} 
- 53,7\% wszystkich innych niż pojedyncza polska identyfikacji narodowo-etnicznych (Gudaszewski, 2015, s. 30).

Deklaracje dotyczące narodowości nie pozostawały w prostej zależności z językiem kontaktów domowych ${ }^{9}$. Wprawdzie wśród osób o wyłącznie niepolskiej identyfikacji narodowościowej w porównaniu z dualnymi, obejmującymi polską, zwiększał się odsetek respondentów używających wyłącznie języków niepolskich z 3,9\% do 19,4\%, a także odsetek osób używających języka polskiego i niepolskiego (z 33,8\% do 40,9\%), tzn. odsetek osób o niepolskich identyfikacjach używał wyłącznie języka polskiego, czyli 62,3\% osób o podwójnych identyfikacjach i odpowiednio 39,5\% o wyłącznie niepolskiej (Gaduszewski, 2015, s. 77).

Analogicznie, wyniki dotyczące relacji pomiędzy wskazaniami języka niemieckiego jako języka kontaktów domowych nie przystawały w pełni do deklaracji przynależności narodowej. Jak podaje Grzegorz Gudaszewski (2015, s. 73) w 2002 roku język niemiecki był w świetle deklaracji częściej stosowany niż wskazywałaby na to liczba deklaracji narodowościowych (204,6 tys. wobec 152,9 tys.). Z kolei w spisie ludności z 2011 roku odnotowano więcej niemieckich identyfikacji narodowościowych (147,8 tys.) niż deklaracji dotyczących posługiwania się w kontaktach domowych językiem niemieckim (96,5 tys.).

Odpowiedzi na pytanie: „Do jakiego wyznania religijnego (kościoła lub związku wyznaniowego) Pan(i) należy?" ujawniły, że relacje pomiędzy deklarowanymi identyfikacjami a przynależnością religijną są złożone. Osoby, które wybierały inną niż polska narodowość w pojedynczych lub podwójnych identyfikacjach, cechowały się różną przynależnością religijną, w tym także odmienną niż dominująca w narodzie (narodowości), z którą się identyfikowały. Na przykład, wśród osób o identyfikacji żydowskiej (7508 osób), wymienianej jako jedyna, lub w podwójnych identyfikacjach jako pierwsza lub druga, 30,3\% przynależało do Kościoła katolickiego, tylko 4,11\% do Związku Gmin Wyznaniowych Żydowskich, a także znaczna część (32,16\%) nie należała do żadnego wyznania ${ }^{10}$ (Gudaszewski, 2015, s. 241). Ponad 40\% osób o identyfikacji ukraińskiej (51 001 osób) należało do Kościoła katolickiego, obrządku bizantyjsko-ukraińskiego, 23,3\% - do Kościoła katolickiego obrządku łacińskiego, 19,7\% - do Kościoła prawosławnego ${ }^{11}$ (s. 240). Być może przynależność religijna decydowała o tym, czy niepolska narodowość była jedyną, pierwszą czy też drugą w złożonych identyfikacjach. Niestety przedstawiony materiał nie pozwala tego stwierdzić.

Ostatecznie wyniki te przekonują, że identyfikacjom z określoną grupą etniczną nie musi towarzyszyć partycypacja w działaniach i zachowaniach charakterystycznych dla tej grupy, respektowanie jej norm i akceptacja wartości grupowych. Jak pisze Modood (2014: 112): „Niektórzy Hindusi na przykład, zwłaszcza należący do drugiego pokolenia, nie nosili się na modłę hinduską, nie uczęszczali regularnie do świątyni, gurdwary czy meczetu albo nie posługiwali się regularnie językiem hinduskim". Pod wieloma względami myśleli jednak o sobie jako o Hindusach (s. 112). Część osób podporządkowywała się tradycyjnym normom i praktykom. Pojawiały się także nowe formy etniczności, a silnym grupowym identyfikacjom towarzyszyło umiarkowane lub nikłe podporządkowanie normom na poziomie behawioralnym. Afiliacyjne tożsamości grupowe nie zawsze łączą się z traktowaniem

\footnotetext{
${ }_{9}^{9}$ Pytanie brzmiało: Jakim(i) językiem(ami) zazwyczaj posługuje się Pan(i) w domu? 1. wyłącznie polskim, 2. polskim i innym (i) niż polski (podać jakim/i) ..., 3. wyłącznie innymi(i) niż polski (podać jakim/i) .... Wybór odpowiedzi 2 lub 3 otwierał dostęp do słownika języków oraz możliwość swobodnego zapisu określenia języka/języków w polu edycji. W przypadku odpowiedzi 2 lub 3 - osoby spisywane mogły zadeklarować używanie dwóch różnych języków niepolskich.

${ }^{10}$ 22,03\% osób odmówiło odpowiedzi, a nie ustalono wyznania 0,66\% osób (Gudaszewski, 2015, s. 241).

${ }^{11}$ 0,51\% należało do Związku Wyznaniowego Świadków Jehowy, 4,07\% nie należało do żadnego wyznania, 8,65\% odmówiło odpowiedzi, nie ustalono wyznania 1,43\% osób (Gudaszewski, 2015, s. 240).
} 
„przynależności grupowej jako implikującej bezruch, czystość kulturową czy też wewnętrzną jednorodność" (Modood i in., 1997, s. 334-338).

Identyfikacje etniczne imigrantów w rzeczywistości niekoniecznie odnoszą się do mało znanych wspólnot pochodzenia przodków, lecz do „imigracyjnych zbiorowości”, określanych niekiedy mianem „nowych etniczności”, jak to nazwał Stuart Hall (1992). Szczególnie dotyczy to kolejnych pokoleń imigrantów, którzy nie zetknęli się nigdy z ziemią ojców, a których „ojczyzną”, obok „wyobrażonej”, jest kraj urodzenia. Niektórzy z potomków imigrantów podkreślają tę specyfikę, określając się mianem zarezerwowanym dla nowej sytuacji, np. ludność maghrebskiego pochodzenia we Francji mówi o sobie „beur”, a nie „Arabe”. Według Modooda (2014, s. 111), przywołującego prace Oliviera Roy’a $(2004,2005)$ nie można na nich patrzeć przez pryzmat arabskiej kultury i etniczności.

Świadectwem odejścia od ojczyźnianych identyfikacji, a nie dziełem przypadku jest, jak można przypuszczać, pojawianie się identyfikacji „kontynentalnych”, a nie narodowych, jak „czarni”, Afroamerykanie, Latynosi, Azjaci. Trudno powiedzieć, na ile są one skutkiem naznaczania przez ludność kraju przyjmującego, która nie rozróżnia, a właściwie często nie jest w stanie rozpoznać kraju pochodzenia „innych”. Przyjmowanie takich identyfikacji przez kolejne pokolenia imigrantów może także dowodzić zaniku łączności z ojczyznami przodków, a konstytuowania własnych tożsamości na zasadzie odróżniania się pod jakimś względem od obecnych obok „innych”.

Obok aspektu afiliacyjnego i behawioralnego ważny jest także kontekst sytuacyjny, a zwłaszcza to, co wiąże się z naznaczaniem oraz wykluczaniem imigranckich lub osiadłych mniejszości. Naznaczanie „innych” przez większość (grupę dominującą) oraz odczuwane przez nich upośledzenie wobec dominującej grupy etnicznej, znajdujące swój wyraz w rzeczywistym (lub wyobrażonym) braku dostępu do społecznie cenionych dóbr, może skutkować „wytworzonymi” identyfikacjami ze „swoimi”, zdefiniowanymi pierwotnie przez „obcych”. Można przypuszczać, że określanie siebie mianem „czarnych”, Afroamerykanów czy Azjatów zawiera komponent stosunku do „innych”, dla których etniczna czy narodowa przynależność potomków przybyszy jest trudna do ustalenia, a zatem korzystają z szerszych kategoryzacji.

Jest też znamienne, że identyfikacja bez łącznika - Afroamerykanie - wytycza zarówno przynależność do węższej zbiorowości, odróżniającej się oraz niepodobnej pod pewnymi względami do innych Amerykanów, ale też afiliację i być może dostrzegane podobieństwo do szerszego kręgu Amerykanów. Trudno powiedzieć, co wysuwa się na plan pierwszy - poczucie dumnej podwójnej przynależności odpowiadające kosmopolitycznej identyfikacji, czy też odczuwane obszary wykluczenia i dyskryminacji. Obie hipotezy są prawdopodobne.

W odniesieniu do złożonych identyfikacji szczególnie ważna jest odpowiedź na pytania o miejsce, rolę i funkcję ich składowych w całości tożsamości jednostek, a także o ich wzajemną relację, o znaczenie przyswojenia narodowej (etnicznej) kultury lub dwóch, a nawet więcej kultur, jak również (a może przede wszystkim) o to, czy autodefinicja wyraża łączność z narodem, czy z państwem, czy świadczy o separacji identyfikacji narodowych od identyfikacji obywatelskich.

Relacja pomiędzy warstwą afiliacyjną a behawioralną nie wyczerpuje złożoności zagadnienia identyfikacji etniczno-narodowych. Należy mieć na uwadze to, że podstawą dokonywanych przez jednostki kategoryzacji może być odczuwane podobieństwo do członków jakiejś zbiorowości czy kategorii społecznej lub przynależność do niej. Jak podkreśla Irena 
Machaj, identyfikacja oparta na przynależności sprzyja formowaniu się behawioralnego wymiaru tożsamości jednostki (2005, s. 58).

Zdarza się jednak, zgodnie z zasadą dynamiki identyfikacji i aspiracjami do przynależności do grup dotąd uznawanych za inne, a nawet obce, że dychotomie podobieństwa i niepodobieństwa oraz przynależności i nieprzynależności ukazują inne możliwości. Można identyfikować się z tymi, do których nie jest się pod wieloma względami podobnym i do których jeszcze się nie należy, lecz do których pragnie się przynależeć, co motywuje do podejmowania działań, które mają sprawić, że stanie się podobnym. Taka sytuacja niejednokrotnie towarzyszy konwersji etnicznej, a wyraża skłonność jednostkowych tożsamości do transcendencji. Przyjmowanie zwyczajów i obyczajów obowiązujących w grupie aspiracji, uczenie się języka, zasad i norm religijnych, poznawanie kultury i historii ma być pierwszym krokiem do zmiany przynależności, dobrowolnego dążenia do asymilacji, niezależnie od tego, czy występuje, czy też nie presja asymilacyjna.

\section{Podsumowanie}

Powyższe rozważania mogą skłaniać do kilku następujących wniosków - postulatów dla badaczy identyfikacji etniczno-narodowych. Należy:

1. Unikać narzucania identyfikacji w badaniach socjologicznych.

2. Nie zadowalać się uzyskaniem odpowiedzi na pytanie: „kim jesteś?”.

3. Rozpoznać, o czym rzeczywiście informują deklarowane identyfikacje, biorąc pod uwagę zarówno aspekt afiliacyjny, jak i behawioralny oraz kontekst sytuacyjny - naznaczanie, wykluczanie, odczuwane upośledzenie.

4. Rozpoznać, z kim i z czym identyfikują się członkowie mniejszości etnicznych, zwłaszcza o złożonych identyfikacjach - z narodem (grupą etniczną), krajem urodzenia czy z państwem osiedlenia? Jaką rolę w tych identyfikacjach odgrywa obywatelstwo kraju osiedlenia?

5. Pamiętać o płynności i plastyczności identyfikacji.

6. Uwzględniać „,nowe etniczności”, hybrydowość kultur i wytwarzanie „trzecich przestrzeni”.

Dla polityków zajmujących się mniejszościami etnicznymi i narodowymi oraz ich integracją w krajach osiedlenia, ważne jest to, by traktować asymilację jako wybór jednostki, a nie przymus wynikający z polityki państwa. Złożone, podwójne identyfikacje, zwłaszcza ukazujące łączność z państwem pobytu (urodzenia) i obowiązujące zasady rzeczywistego, a nie tylko formalnego obywatelstwa mogą sprzyjać integracji, a także lojalności osób o tych identyfikacjach.

\section{LITERATURA}

Beck, U. (2005). Władza i przeciwwładza w epoce globalnej. Nowa ekonomia polityki światowej. Warszawa: Scholar.

Beck, U., Grande, E. (2009). Europa kosmopolityczna. Społeczeństwo i polityka w drugiej nowoczesności. Warszawa: Scholar.

Brubaker, R. (1998). Nacjonalizm inaczej. Struktura narodowa i kwestie narodowe w nowej Europie. Kraków: Wydawnictwo Naukowe PWN.

Erikson, E.H. (2000). Dzieciństwo i społeczeństwo. Poznań: Dom Wydawniczy Rebis. 
Gudaszewski, G. (2015). Struktura narodowo-etniczna, językowa i wyznaniowa ludności Polski. Narodowy Spis Powszechny Ludności i Mieszkań 2011. Warszawa: GUS. Pobrano z: http:// stat.gov.pl/files/gfx/portalinformacyjny/pl/defaultaktualnosci/5670/22/1/1/struktura_narodowo-etniczna.pdf (14.09.2015).

Gupta, A., Ferguson, J. (2004). Poza „kulturę”: przestrzeń, tożsamość i polityka różnicy. W: M. Kempy, E. Nowicka (red.), Badanie kultury. Elementy teorii antropologicznej. Kontynuacje (267-283). Warszawa: Wydawnictwo Naukowe PWN.

Hall, S. (1992). New Ethnicities. W: J. Donald, A. Rattansi (ed.), "Race”, Culture and Difference (252-259). London: Sage Publications.

Kłoskowska, A. (1992). Tożsamość i identyfikacja narodowa w perspektywie historycznej i psychologicznej. Kultura i Społeczeństwo, 1, 131-141.

Kłoskowska, A. (1996). Kultury narodowe u korzeni. Warszawa: Wydawnictwo Naukowe PWN.

Machaj, I. (2005). Społeczno-kulturowe konteksty tożsamości mieszkańców wschodniego i zachodniego pogranicza Polski. Warszawa: Wydawnictwo Naukowe Scholar.

Merton, R.K. (1982). Teoria socjologiczna i struktura społeczna. Warszawa: PWN.

Modood, T. (2014). Multikulturalizm. Poznań: Wydawnictwo Nauka i Innowacje.

Modood, T., Berthoud, R., Lakey, J., Nazroo, J., Smith, P., Virdee, S., Beishon, S. (1997). Ethnic Minorities in Britain: Diversity and Disadventage. London: Policy Studies Institute.

Ossowski, S. (1984). Analiza socjologiczna pojęcia ojczyzny. Dzieła. T. III. Warszawa: PWN.

Parsons, T. (1972). Szkice z teorii socjologicznej. Warszawa: PWN.

Raciborski, J. (2011). Obywatelstwo w perspektywie socjologicznej. Warszawa: Wydawnictwo Naukowe PWN.

Roy, O. (2004). Globalised Islam. London: C. Hurst.

Roy, O. (2005). A Clash of Cultures or a Debate on Europe's Values. ISIM (International Institute for the Study of Islam in the Modern World) Review. Spring, 6-7.

Said, E.W. (1979). Zionism from the Standpoints of the Victims. Social Text, 1 (1), 7-58.

Suchocka, R. (2003). Widnokrąg społeczny a przekraczanie granic. W: M. Zielińska (red.), Transgraniczność w perspektywie socjologicznej. Teorie, studia, interpretacje (83-98). Zielona Góra: Lubuskie Towarzystwo Naukowe.

Suchocka, R. (2014). Mieszkańcy Europy, Europejczycy i ich widnokręgi społeczne. Poznań: Wydawnictwo Naukowe UAM.

Szacka, B. (2008). Wprowadzenie do socjologii. Warszawa: Oficyna Naukowa.

Tajfej, H. (1972). La catégorisation sociale. W: S. Moscovici (red.), Introduction à la psychologie sociale. Vol. 1, 272-302. Paris: Larousse.

Tajfel, H. (1982). Social Identity and Intergroup Relations. Cambridge: Cambridge University Press.

Turner, J.C. (1992). Ku poznawczej redefinicji pojęcia „grupa społeczna”. W: J. Szmatka (red.), Elementy mikrosocjologii. Wybór tekstów. Cz. II (81-109). Kraków: Wydawnictwo UJ.

Waldenberg, M. (2000). Narody zależne i mniejszości narodowe w Europie Środkowo-Wschodniej. Warszawa: Oficyna Naukowa.

Young, D. (1937). American Minority Peoples. New York: Harper \& Brot. B. Readings on Specific Nationality Groups. 


\section{KEYWORDS}

NATIONAL IDENTIFICATION, ETHNIC IDENTIFICATION, SOCIAL IDENTITY, COMPLEX IDENTIFICATION, IMMIGRANTS
SUMMARY The aim of this study is to draw attention to the intricacies of identification in the societies in which identification is increasingly becoming a matter of choice, not "heredity". The subject of the discussion includes the complex identification occurring in multinational and multi-ethnic countries, different identities of their residents and citizens, immigrants, and particularly their descendants, including double or cosmopolitan identifications, constructed and not "transferred" by the ancestors. What do declarations, treated as relating to the national (ethnic) identification, actually mean? Do they inform of the identification with the nation, homeland or the state? The relations between the different types of national and (or) ethnic identification can determine people's attitudes towards the state of residence, the nation and the country of settlement and origin (the country of their ancestors). The knowledge of these relationships is especially important for interpreting the complex identifications being declared, and for understanding the national conversion. 